\title{
Stream ecosystem properties and processes along a temperature gradient
}

\author{
Jes Jessen Rasmussen • \\ Annette Baattrup-Pedersen • \\ Tenna Riis $\cdot$ Nikolai Friberg
}

Received: 7 July 2010/Accepted: 30 December 2010/Published online: 14 January 2011

(C) The Author(s) 2011. This article is published with open access at Springerlink.com

\begin{abstract}
We surveyed macrophyte community structure and measured community metabolism and nutrient uptake along a temperature gradient $\left(9.7-17.4^{\circ} \mathrm{C}\right)$ in four Icelandic streams influenced by geothermal heating. The study streams are part of the geothermal area in Hengill that is uniquely characterised by streams with comparable water chemistry despite the geothermal influence. Stream metabolism was studied applying the diurnal upstream-downstream dissolved oxygen change technique. Nutrient uptake was studied by adding solutions of nitrogen and phosphorus together with a conservative tracer. Rates of primary production (GPP) and uptake of nitrate-N and phosphate-P increased with increasing stream temperature. GPP was 20 times higher (up to $12.99 \mathrm{~g}$ $\mathrm{O}_{2} \mathrm{~m}^{-2}$ day $^{-1}$ ) and rates of nutrient uptake were up to 30-times higher (up to 22.99, 13.31 and $7.94 \mathrm{mg}$ $\mathrm{m}^{-2} \mathrm{~h}^{-1}$ for ammonium, nitrate and phosphate,
\end{abstract}

Handling Editor: Michael T. Monaghan.

J. J. Rasmussen $(\varangle) \cdot$ A. Baattrup-Pedersen · N. Friberg National Environmental Research Institute, Aarhus University, Aarhus, Denmark

e-mail: jr@dmu.dk

T. Riis

Department of Biological Sciences, Aarhus University, Aarhus, Denmark

\section{N. Friberg}

Macaulay Land Use Research Institute, Catchment

Management Group, Craigebuckler, Aberdeen, UK respectively) in the warmest streams compared with the coldest. Furthermore, macrophytes, when present, were strongly controlling ecosystem processes. Our study implies that temperature may affect stream ecosystem processes both directly (i.e. physiologically) and indirectly (i.e. by changing other structural parameters).

Keywords Metabolism - Nutrient uptake · Macrophytes $\cdot$ Temperature $\cdot$ Streams

\section{Introduction}

Temperature is one of the main factors governing the biological performance of species and their interactions, setting outer limits for species distribution locally, regionally and globally (Heino 2002; Lacoul and Freedman 2006). In consequence of increasing earth surface temperature $\left(3-5^{\circ} \mathrm{C}\right.$ during the next 100 years, IPCC 2007), resulting from the ongoing climate change, these outer boundaries are relocated, and the performance of species changes. The impact of increasing temperature on ecosystem structure and function is proposed to be pronounced (Hickling et al. 2006; Friberg et al. 2009).

Increasing temperature has a direct and indirect effect on the stream biota. Direct effects on the level of organisms include increasing enzymatic activity (Ward and Stanford 1982) and (if resources are sufficient) increasing growth rates (Carr et al. 1997; 
Lacoul and Freedman 2006). However, speciesspecific traits in regard to temperature tolerance are of crucial importance to their actual response to increasing temperature; growth conditions for some species improve due to increasing temperature, other species experience an adverse effect on growth conditions, competitive abilities or they may even become locally extinct (Crow 1993; Jacobsen et al. 1997; Friberg et al. 2009).

Increasing temperature is, furthermore, likely to induce an indirect acceleration of certain ecosystem processes through combined effects on biological organisms and their functional performance and rates of diffusion and chemical reactions (Enquist et al. 2003; Brown et al. 2004; Vallett et al. 2008). Several studies have indicated increasing rates of organic matter decomposition with increasing temperature induced by microbial components (Rowe et al. 1996; Friberg et al. 2009). Additionally, previous studies comparing streams and river systems spatially (along latitudinal gradients) or temporally (between seasons or time of day) suggest increasing rates of nutrient uptake, photosynthesis and respiration with increasing temperature (e.g. Mulholland et al. 1985, 2006; Fellows et al. 2006). However, light intensity and the length of light period strongly govern both in-stream temperature regimes and rates of ecosystem nutrient uptake and metabolism (Mulholland et al. 1985; Simon and Townsend, 2005). Other parameters (e.g. hydrological regimes, $\mathrm{pH}$ and nutrient concentrations) vary spatially as well as temporally among streams. Consequently, it is difficult to obtain sufficient replication when studying the effects of increasing temperature on ecosystem structure and function in natural streams.

Geothermally heated streams provide a promising opportunity to study the effects of increasing temperature, because they often represent a large thermal gradient within a relatively small geographical area. Due to the proximity, dispersal barriers are not prominent (Petersen et al. 2004), and physical properties (e.g. flow characteristics and substratum), irradiance and hydrological regimes are often comparable. Differences in water chemistry among geothermally heated streams, unfortunately, frequently occur due to the geothermal activity. However, we have recently identified a new study site that meets all above-mentioned criteria. The site is situated in the Hengill valley (a geothermal area in Iceland) consisting of 15 low-order streams discharging into River
Hengladalir. We have applied this site to test various hypotheses related to the impact of climate warming. The first studies showed strong increases in primary production and organic matter decomposition with increasing temperature and, furthermore, indicated high species turnover rates and basic differences in food chain structure between streams differing in temperature (Friberg et al. 2009; Woodwards et al. 2010).

Traditional stream ecosystem quality assessment is based on the structural composition of biological communities, but monitoring of functional elements of stream ecosystems are, additionally, highly relevant because stressors do not necessarily impact ecosystem structure and function equally (Gessner and Chauvet 2002). Elemental cycling and energy flow are fundamental ecosystem processes that are tightly linked from metabolic reactions at the level of stoichiometry to linkages at ecosystem level (Redfield 1958; Elser et al. 1996; Fellows et al. 2006). For both autotrophs and heterotrophs, low nutrient availability can limit metabolism and, conversely, rates of metabolism control rates of nutrient uptake, transformation and release (Hall and Tank 2003; Fellows et al. 2006).

In this study, we use the geothermally heated streams in Hengill to interconnect nutrient uptake and metabolism representing ecosystem function with temperature and macrophyte community structure. The aim of this study was (1) to investigate the influence of temperature on stream ecosystem metabolism and nutrient uptake and (2) to investigate whether potentially temperature-induced differences in ecosystem properties (macrophyte community structure) translates into magnified effects of temperature on ecosystem function (metabolism and nutrient uptake).

\section{Materials and methods}

Study site

The study was conducted in four first- and secondorder streams in the Hengill area between 27 July and 14 August 2006. The Hengill area is situated $30 \mathrm{~km}$ east of Reykjavik, Iceland $\left(64^{\circ} 03^{\prime} \mathrm{N}\right.$ : $\left.021^{\circ} 18 \mathrm{~W}\right)$. The study streams are a subset of a larger set of geothermal streams used in previous studies (Friberg et al. 2009; Woodwards et al. 2010). Selective criteria were (1) 
study reach lengths should be sufficient for metabolism and nutrient uptake measurements and (2) reaches should not have significant water input from tributaries or groundwater. All streams are situated 3-400 m above sea level. Average seasonal air temperature amplitude ranges from -20 to $20^{\circ} \mathrm{C}$. Average seasonal precipitation exceeds $3,000 \mathrm{~mm}$ year $^{-1}$. Geothermal hotspots are randomly distributed in the study area. Consequently, water temperature differs among streams depending on the interface between springs and geothermal hotspots. The catchment is dominated by grasslands and volcanic rock.

\section{Stream characteristics and biology}

The lengths of study reaches ranged from 75 to 110 metres with survey transects established every two metres. In each transect, wetted width, depth and water velocity $(0.4 \times$ depth $)$ were measured at four points corresponding to $25,50,75$ and $100 \%$ of the wetted width. Average values for stream depth and water velocity were based on all transect points. Average discharge calculations were based on the calculated discharge in each transect $(\mathrm{D} \times \mathrm{W} \times \mathrm{U})$. Between each pair of transects, four rectangular plots were established $(2 \mathrm{~m} \times 25 \%$ of wetted width). In each plot, substratum type and total macrophyte coverage were estimated. Macrophytes were identified to the lowest possible taxonomical level, and species-specific relative coverage was estimated. Stream water temperature was measured in the study period using temperature loggers (Onset 32K StowAway TidBit loggers) every $30 \mathrm{~min}$.

We collected two water samples $(250 \mathrm{ml})$ from each stream. One was filtrated in the field using glass microfibre filters (Whatman GFF, $0.7 \mu \mathrm{m}$ pore size) and one was stored unfiltered. Each filtered water sample was analysed for nitrate, ammonium, phosphate and chloride. Concentrations of ammonium, nitrate and phosphate were measured using Lachatmethods (Lachat Instruments, USA, Quickchem. No. 10-107-06-33-A (Salycate method), 10-107-04-1-C and 10-115-01-1-A, respectively). Chloride $\left(\mathrm{Cl}^{-}\right)$ concentrations were measured using titration with $\mathrm{AgNO}_{3}$ (APHA, 1989). Concentrations of total $\mathrm{N}$ and total $\mathrm{P}$ were measured (unfiltered samples) applying the Kjeldahl-N method (Kjeldahl 1883) and Danish standard (DS-291), respectively. pH was measured applying a (YSI-60) pH-meter.
Nutrient uptake

Nutrient uptake parameters were measured in each stream, applying single additions of phosphate $\left(\mathrm{Na}\left(\mathrm{H}_{2} \mathrm{PO}_{4}\right) \cdot \mathrm{H}_{2} \mathrm{O}\right)$, ammonium and nitrate $\left(\mathrm{NH}_{4} \mathrm{NO}_{3}\right)$ concurrently with chloride $(\mathrm{NaCl})$ as a conservative tracer. All nutrients were added simultaneously in one mixture. Nutrient concentrations were adjusted to elevate background concentrations by a factor 3 to minimise saturation conditions. During nutrient release, conductivity was continuously measured (in a well-mixed area) in the terminal end of the study reach (Jenway conductivity meter), and values were logged at 30 -s intervals. Conductivity was used to define the time of offset plateau concentration and to calculate discharge during nutrient release (applied in calculation of nutrient uptake parameters). In each stream duplicate, water samples were collected from well-mixed areas at eight sampling sites before offsetting nutrient release. Furthermore, another duplicate sampling was conducted at plateau concentration. The sampling sites were defined by their distance to the upstream end $(5,7,10,15,20,30,50$ and 75-110 m (depending on the reach length)). Sites for well-mixed areas were identified prior to nutrient additions ( $\mathrm{NaCl}$ additions). All water samples were collected in 250-ml plastic bottles and filtrated immediately after sampling (glass microfibre filters, Whatman GFF, $0.7 \mu \mathrm{m}$ pore size). Samples were stored in cooling boxes in the field and, subsequently, stored in a freezer at the University of Reykjavik. Nutrient concentration was measured, following the procedures applied for general water chemistry analyses. Duration of each nutrient addition experiment was 1-2 h, depending on stream characteristics. Irradiation was measured using Licor (LI-1400) logger and probes at the stream bank during nutrient release, and data was logged at 30-s intervals. All nutrient additions were conducted 1-4 days after stream metabolism measurements in the respective streams to minimise disturbance. For further details on field methods see Webster and Valett (2006).

Estimated uptake of ammonium, nitrate and phosphate was based on measured downstream decrease in concentrations of the respective solutes. In order to eliminate nutrient concentration changes due to hydrological processes, nutrient concentrations were normalised by the added concentrations of chloride at each sampling site (Bencala et al. 1987). The 
relationship between normalised nutrient concentrations $(C)$ and distance from nutrient release point $(x)$ will have a negative exponential curve:

$C_{\mathrm{x}}=C_{0} \times \exp \left(-k_{\mathrm{w}} x\right) \Leftrightarrow \ln \left(C_{\mathrm{x}}\right)=\ln \left(C_{0}\right)-k_{\mathrm{w}} x$

where $C_{0}$ and $C_{\mathrm{x}}$ are normalised nutrient concentrations at the upstream end of the study reach and downstream sampling site, respectively, $x$ corresponds to the distance between the two sampling points, and $k_{\mathrm{w}}$ is the downstream nutrient change coefficient (slope of the linear model). Based on $k_{\mathrm{w}}$ nutrient uptake length $\left(S_{\mathrm{w}}\right)(\mathrm{m})$, nutrient uptake velocity $\left(v_{\mathrm{f}}\right)\left(\mathrm{ms}^{-1}\right)$ and areabased nutrient uptake rate $(U)\left(\mathrm{mg} \mathrm{m}^{-2} \mathrm{~h}^{-1}\right)$ were calculated according to standardised protocols (Stream Solute Workshop 1990; Webster and Valett 2006).

\section{Ecosystem metabolism}

Daily gross primary production (GPP), community respiration $\left(\mathrm{CR}_{24}\right)$ and net daily metabolism (NDM) were measured using the diurnal upstream-downstream dissolved oxygen (DO) change technique (Bott 2006). Oxyguard (model 840) probes and loggers were used, and data was logged at 1-min intervals. The equipment was deployed in each stream for $48 \mathrm{~h}$, and probes were fixated in a wellmixed area at the upstream and downstream end. During the experiments, irradiation was monitored at the stream bank using a Licor (LI-1400) probe and data logger. Data were logged at 30-s intervals. Furthermore, discharge and air-water gas exchange rate were measured during the experiments using a simultaneous steady-state injection of chloride $(\mathrm{NaCl})$ as the conservative tracer and propane as the volatile tracer (Marzolf et al. 1994). Stream water conductivity was measured (Jenway conductivity meter) during tracer additions to indicate the offset of steady-state conditions. At steady-state conditions, triplicate water samples were collected at six sampling sites corresponding to 5, 7, 10, 15, 20 and $25 \mathrm{~m}$ from the upstream end. Sampling sites (well-mixed conditions) were identified prior to nutrient additions by adding $\mathrm{NaCl}$ and measuring conductivity along the reach. Furthermore, stream water conductance was measured at all sampling points during steady-state conditions (Jenway conductivity meter) and, subsequently, used for metabolism calculations. Water samples were collected in airproof glass vials $(5 \mathrm{ml})$ with silicone membranes. Water was injected into the glass vials with a syringe and immediately sent to the Centre d'Estudis Avançats de Blanes, Girona, Spain for propane analyses. Propane analyses were based on gas chromatography (Marzolf et al. 1994).

The air-water exchange rate for propane was determined from the first-order rate constant of propane concentration decline with increasing distance to the propane injection point. The air-water oxygen exchange rate was calculated by multiplying propane gas exchange rates with 1.39 (Rathbun et al. 1978). Furthermore, the oxygen exchange rate values were corrected for dilution due to increase in discharge. Dilution was quantified from discharge calculations on upstream and downstream sampling sites (Bott 2006). Oxygen exchange rates based on propane injections are designated $k_{\text {oxygen }}$.

An alternative air-water exchange rate for oxygen was calculated using the Energy Dissipation Model (EDM; Tsivoglu and Neal 1976). When applying the EDM model, the estimated reaeration for oxygen is based on the assumption that stream water temperature is $20^{\circ} \mathrm{C}$. Therefore, estimated reaeration for oxygen was adjusted to the measured stream temperature during propane injection by multiplying with $1.024^{(t-20)}$ where $t$ is the measured stream temperature (Elmore and West 1961). Oxygen exchange rates based on the EDM model are designated $k_{2}$.

Rates of net DO change (net metabolism) were determined as the difference in DO concentration between the deployed upstream and downstream probes corrected for air-water oxygen exchange and average water depth at the study reach. Night-time respiration was calculated as the sum of net metabolism during the night. Daytime respiration was determined by extrapolating night-time respiration rates to daytime. $\mathrm{CR}_{24}$ was determined as the sum of night-time and daytime respiration. GPP was determined as the sum of the difference between daytime respiration and measured net metabolism. For further details on methodology and calculations, consult Bott (2006).

Data analysis

Applied level of significance was $P<0.05$ for all statistical tests. Possible correlations between measured physical, chemical and biological parameters were tested with Spearman's rank correlation analysis. Homogeneity of variance was tested with Cochran's 
$C$-test. Median stream temperature (excluding 15\% of the highest and lowest temperature measurements) was applied as temperature parameter. Similarity of daytime irradiance intensity levels during metabolism and nutrient uptake measurements were tested using oneway ANOVA in Stat Graphics 4.1. Linear regressions (including regressions for uptake length calculations (data not shown)) were performed using Stat Graphics plus $4.1(P<0.05) . R^{2}$ values are only presented for significant regressions.

Assessing ecosystem nutrient uptake based on single nutrient additions is proposed to prompt some uncertainty in the results compared with isotopic tracer studies (Mulholland et al. 2002) and multiple nutrient additions (Payn et al. 2005). Considering the low background concentrations of nitrogenous compounds, these stream communities might be nitrogenlimited to some extent, and the measured uptake of nitrogenous compounds could therefore be overestimated as macrophytes respond stronger to the first pulse of added nutrients compared with repetitive pulses (Mulholland et al. 2002).

\section{Results}

Stream characteristics

Median water temperature ranged from 9.7 to $17.4^{\circ} \mathrm{C}$ among streams and amplitudes were generally low reflecting short distances between study reach and spring (Table 1). Groundwater input was minimal at all study reaches. Irradiance levels did not significantly differ among streams $(P<0.05)$, and differences reflect varying overcast conditions during the study period. Nutrient concentrations were comparable and low. However, the concentration of total phosphorous increased with median stream temperature $(P<0.05, r=0.980)$.

\section{Vegetation}

Plant communities differed among streams in terms of species richness, dominant species and coverage (Online resource 1). Fontinalis antipyretica (Hedw.) (Bryopsida, Fontinalaceae) was the dominant macrophyte species in streams S1 and S2 covering approximately $50 \%$ of the stream bed. True submersed vascular plants (Callitriche stagnalis (Scop.), Ranunculus confervoides (Fries) and Potamogeton filiformis (Pers.)) and bryophytes $(F$. antipyretica) were only registered in warmer streams. Macrophyte species richness was higher in warmer streams primarily due to submerged and emerged vascular plants and bryophyte species. Total macrophyte and bryophyte coverage increased significantly with increasing median stream temperature $(P<0.05, r=0.985$ and $r=0.967$; Fig. 1$)$.

Nutrient uptake and stream metabolism

Uptake length $\left(S_{\mathrm{w}}\right)$ for ammonium ranged from $17.6 \mathrm{~m}$ in $\mathrm{S} 1$ to $82.6 \mathrm{~m}$ in S4. $S_{\mathrm{w}}$ for nitrate ranged from $31.0 \mathrm{~m}$ in $\mathrm{S} 2$ to $169.5 \mathrm{~m}$ in S4 (Fig. 2). Uptake rates (U) for ammonium ranged from $1.52 \mathrm{mg} \mathrm{m}^{-2} \mathrm{~h}^{-1}$ in $\mathrm{S} 4$ to $22.99 \mathrm{mg} \mathrm{m}^{-2} \mathrm{~h}^{-1}$ in $\mathrm{S} 1$, and $\mathrm{U}$ for nitrate ranged from $0.44 \mathrm{mg} \mathrm{m}^{-2} \mathrm{~h}^{-1}$ in S4 to $13.31 \mathrm{mg} \mathrm{m}^{-2} \mathrm{~h}^{-1}$ in $\mathrm{S} 1$ (Fig. 2). $S_{\mathrm{w}}$ for phosphate ranged from 150 to $300 \mathrm{~m}$. U for phosphate ranged from $1.16 \mathrm{mg} \mathrm{m}^{-2} \mathrm{~h}^{-1}$ in S4 to $7.94 \mathrm{mg} \mathrm{m}^{-2} \mathrm{~h}^{-1}$ in S1, respectively (Fig. 2). $\mathrm{U}$ for phosphate in $\mathrm{S} 2$ was high despite low uptake velocity $\left(v_{\mathrm{f}}\right)$ due to high background concentrations of phosphate.

Median stream temperature was significantly correlated with $\mathrm{U}$ for nitrate and phosphate $(P<0.05)$, but insignificantly with ammonium $(P=0.051$; Fig. 3). U for phosphate was significantly correlated with total macrophyte coverage $(P<0.05)$, but this was not the case for nitrate and ammonium ( $P=0.059$ and $P=0.061$, respectively; Fig. 3 ).

Applying $k_{\text {oxygen }}$ as reaeration coefficient, GPP ranged from $0.66 \mathrm{~g} \mathrm{DO} \mathrm{m}^{-2}$ day $^{-1}$ in $\mathrm{S} 4$ to $12.99 \mathrm{~g}$ DO $\mathrm{m}^{-2}$ day $^{-1}$ in S1 (Table 2). Community respiration $\left(\mathrm{CR}_{24}\right)$ ranged from $5.55 \mathrm{~g} \mathrm{DO} \mathrm{m}^{-2}$ day $^{-1}$ in $\mathrm{S} 4$ to $25.46 \mathrm{~g} \mathrm{DO} \mathrm{m}^{-2} \mathrm{day}^{-1}$ in S1. Net daily metabolism (NDM) was negative for all streams during metabolism measurements, but $\mathrm{P} / \mathrm{R}$ relationships increased from 0.12 in the coldest stream (S4) to 0.61 in the warmest stream (S1). Applying measured or calculated reaeration coefficients ( $k_{\text {oxygen }}$ and $k_{2}$, respectively) did not produce significantly different results $(P<0.05$; Table 2). GPP increased significantly with increasing median stream temperature $(P<0.05, r=0.959)$ and with bryophyte and total plant coverage $(P<0.05$, $r=0.931$ and $r=0.930$, respectively; Fig. 4).

GPP was significantly correlated with $\mathrm{U}$ for nitrate, ammonium and phosphate $(P<0.05, r=0.998$, $r=0.999$ and $r=0.994$, respectively; Fig. 5). $\mathrm{CR}_{24}$ was significantly correlated with $\mathrm{U}$ for nitrate and 
Table 1 Physical and chemical properties of four steams influenced by varying geothermal activity

\begin{tabular}{|c|c|c|c|c|}
\hline & $\mathrm{S} 1$ & $\mathrm{~S} 2$ & $\mathrm{~S} 3$ & S4 \\
\hline \multicolumn{5}{|l|}{ Physical properties } \\
\hline Median water temperature $(\mathrm{C}) \pm \mathrm{SD}$ & $17.4 \pm 1.05$ & $17.1 \pm 0.6$ & $12.4 \pm 2.0$ & $9.7 \pm 1.4$ \\
\hline Study reach $(\mathrm{m})$ & 75 & 110 & 100 & 100 \\
\hline Depth $(\mathrm{m}) \pm \mathrm{SD}$ & $0.11 \pm 0.05$ & $0.10 \pm 0.02$ & $0.12 \pm 0.04$ & $0.07 \pm 0.05$ \\
\hline Width $(\mathrm{m}) \pm \mathrm{SD}$ & $1.65 \pm 0.73$ & $1.59 \pm 0.77$ & $4.94 \pm 0.34$ & $1.86 \pm 1.08$ \\
\hline Slope $\left.\left(\mathrm{m} \mathrm{m}^{-1}\right) 1\right)$ & 0.018 & 0.02 & 0.015 & 0.02 \\
\hline Discharge $\left(\mathrm{m} 3 \mathrm{~s}^{-1}\right) \pm \mathrm{SD}$ & $0.026 \pm 0.009$ & $0.031 \pm 0.009$ & $0.043 \pm 0.014$ & $0.022 \pm 0.12$ \\
\hline Groundwater input (\%) & 2.6 & 3.8 & 2.0 & 2.4 \\
\hline Avg. $\mathrm{O} 2$ concentration $\left(\mathrm{mg} \mathrm{l}^{-1}\right) \pm \mathrm{SD}$ & $8.85 \pm 0.85$ & $8.06 \pm 0.39$ & $9.61 \pm 0.72$ & $11.07 \pm 0.05$ \\
\hline Avg. irradiation $\left(\mu \mathrm{mol}\right.$ photons $\left.\mathrm{m}^{-2} \mathrm{~s}^{-1}\right) \pm \mathrm{SD}$ & $152.5 \pm 86.5$ & $126.8 \pm 78.7$ & $211.3 \pm 128.2$ & $268.2 \pm 238.6$ \\
\hline $\mathrm{pH}$ & 7.8 & 8.0 & 7.8 & 8.1 \\
\hline \multicolumn{5}{|l|}{ Substratum } \\
\hline$\%$ Boulder $(>60 \mathrm{~mm})$ & 6 & 1 & - & 52 \\
\hline$\%$ Cobble $(10-60 \mathrm{~mm})$ & 18 & 21 & 1 & 33 \\
\hline \% Gravel $(3-10 \mathrm{~mm})$ & 8 & 44 & 66 & 12 \\
\hline$\%$ Coarse sand $(1-3 \mathrm{~mm})$ & 19 & 10 & 30 & - \\
\hline$\%$ Fine sand $(0.25-1 \mathrm{~mm})$ & 21 & 10 & 1 & - \\
\hline$\%$ Mud (black, $<0.25 \mathrm{~mm}$ ) & 24 & 11 & - & - \\
\hline \multicolumn{5}{|l|}{ Chemical properties } \\
\hline Tot. $\mathrm{P}\left(\mu \mathrm{g}^{-1}\right)$ & 33 & 31 & 22 & 15 \\
\hline Tot. $\mathrm{N}\left(\mu \mathrm{g} \mathrm{1^{-1 }}\right)$ & 150 & $<100$ & 180 & $<100$ \\
\hline PO43 - $\left(\mu \mathrm{g}^{-1}\right)$ & 19 & 31 & 21 & 14 \\
\hline $\mathrm{NO} 3-\left(\mu \mathrm{g} 1^{-1}\right)$ & 10 & 5 & 8 & 5 \\
\hline $\mathrm{NH} 4+\left(\mu \mathrm{g} \mathrm{1^{-1 }}\right)$ & 6.4 & 10 & 11 & 5 \\
\hline $\mathrm{Cl}-\left(\mathrm{mg} \mathrm{l}^{-1}\right)$ & 4.87 & 2.58 & 4.18 & 3.81 \\
\hline
\end{tabular}

Temperatures (for the 19 days study period; $n=54,720)$ and DO (2 days monitoring per stream; $n=5,760)$ are indicated as average \pm SD. Average irradiance level is based on light periods from two consecutive days ( $1 \mathrm{~h}$ after dawn to $1 \mathrm{~h}$ before dusk) measured at stream banks $(n=2,400)$. Discharge, depth and width are indicated as average $\pm \mathrm{SD}(n=39$ for S1, $n=56$ for S2, $n=51$ for S3 and S4)

ammonium $(P<0.05, \quad r=0.967$ and $r=0.978$, respectively; data not shown).

\section{Discussion}

Ecosystem function

We found higher $\mathrm{P} / \mathrm{R}$ relationships $(1>\mathrm{P} / \mathrm{R}>0.5)$ in S1 and S2 than in S3 and S4 $(<0.5)$. According to the transitional P/R (Rosenfeld and Mackay 1987), this reflects increasing predominance of autotrophic processes with increasing temperature in these streams. The prevailing overcast conditions during the experimental period are characteristic for the Icelandic summer on the South coast, where less than $40 \%$ of all summer days are dry (Einarsson 1985). However, ecosystem metabolism changes with increasing irradiance (Carr et al. 1997; Mulholland et al. 2001), and as metabolism measurements on clear sky days are not represented in this study, our results are likely to underestimate the mean autotrophic production during summer.

We found increasing rates of ecosystem GPP, CR and nutrient uptake with increasing temperature, indicating temperature-induced increases in enzymatic activity and element diffusion rates. Several previous studies link increasing temperature with 


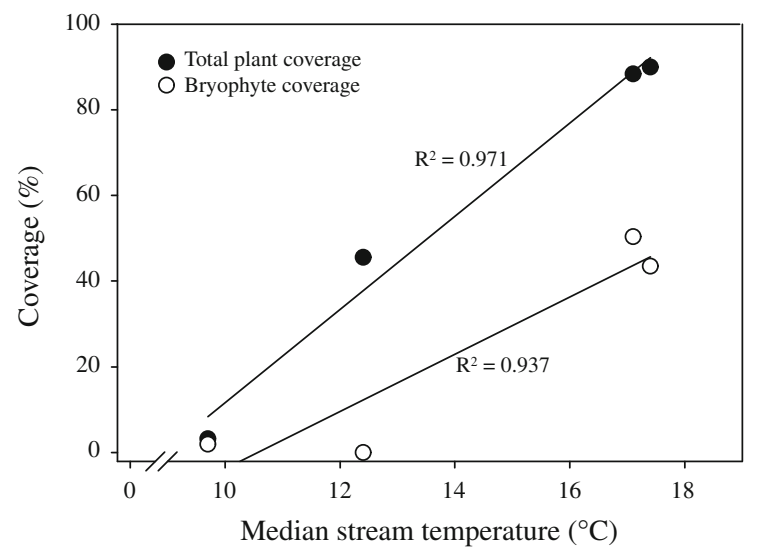

Fig. 1 Total plant coverage and bryophyte coverage as a function of median stream temperature. Linear regression curves have been fitted to the data, and $R^{2}$ values are given

increasing photosynthesis, respiration and nutrient uptake in terms of photoautotrophic organisms (e.g. Maberly 1985; Pilon and Santamaría 2001). However, assuming that temperature is the single factor regulating ecosystem rates of, e.g. photosynthesis and respiration, Boltzmann's factor $\left(\mathrm{e}^{-\mathrm{E} / \mathrm{kT}}\right)$ should link well to our results, because photosynthesis and respiration are processes that obey the physical and chemical laws that govern the transformations of energy and materials (Arrhenius 1915; Brown et al. 2004). On the molecular level, photosynthesis and respiration respond differently to temperature increments due to different activation energies of Rubisco carboxylation and the respiratory complex, respectively; rates of respiration will increase more rapidly than primary production with increasing temperatures (Enquist et al. 2003; Acuña et al. 2008). In this study, GPP increased fourfold compared with CR with increasing temperature, reflecting that the direct effect of temperature is not the primary factor controlling ecosystem processes in these streams.

GPP and nutrient uptake increased with increasing macrophyte coverage, reflecting that photoautotrophic biomass strongly controlled ecosystem metabolism and nutrient uptake. Naturally, increasing autotrophic biomass augments ecosystem GPP (e.g. Kelly et al. 1983; Marzolf et al. 1994) and nutrient uptake (e.g. Stream Bryophyte Group 1999; McKnight et al. 2004). High macrophyte coverage furthermore increases the total habitat surface area, prompting further growth of periphyton, which probably acts as a reinforcing factor.
Photoautotrophic organisms often regulate nutrient spiralling and ecosystem metabolism in streams, even in small canopied forest streams dominated by periphyton (Hall and Tank 2003; Fellows et al. 2006; Mulholland et al. 2006).

In general, rates of GPP, CR and nutrient uptake were very high in the warmest streams ( $\mathrm{S} 1$ and $\mathrm{S} 2$ ), exceeding previous measurements from temperate nutrient rich streams draining agricultural catchments (Bernot et al. 2006; Ensign and Doyle 2006). The Hengill streams are rather closed systems with relatively low allochthonous input of organic matter and nutrients, light is the main source of energy and productivity is probably mainly maintained by internal cycling. Theoretically, it is plausible that temperature drives ecosystem metabolism in such systems (Enquist et al. 2003; Brown et al. 2004), which was supported empirically by Vallett et al. (2008). Our results therefore seem to indicate extremely short spiral length within these systems facilitating the high productivity. Alternatively, the high plant coverage recorded in the warmest streams might act as a confounding factor, potentially magnifying the effects of temperature on rates of ecosystem metabolism and nutrient uptake. Furthermore, our study seriously questions preliminary suggestions that the Hengill streams are nutrient-limited (Friberg et al. 2009).

Ecosystem GPP and area-based uptake rates (U) for nitrate- $\mathrm{N}$, ammonium- $\mathrm{N}$ and phosphate-P were proportionally correlated, indicating that energy produced in primary production is utilised for nutrient uptake and transformation (biomass production). Proportionality between GPP and ecosystem uptake of nitrate-N has been reported from other studies as well (Hall and Tank 2003; Fellows et al. 2006; Mulholland et al. 2006). The light-driven rates of GPP and the uptake of nitrate-N are probably particularly evident, as energy is required for compound reduction prior to its use in cellular synthesis. In this study, however, proportional relationships were evident between GPP and all three tested nutrients: nitrate- $\mathrm{N}$, ammonium-N and phosphate-P. This probably reflects that photoautotrophic biomass was a stronger controlling parameter for ecosystem GPP and nutrient uptake than direct temperatureinduced increments of enzymatic activity and element diffusion rates. 

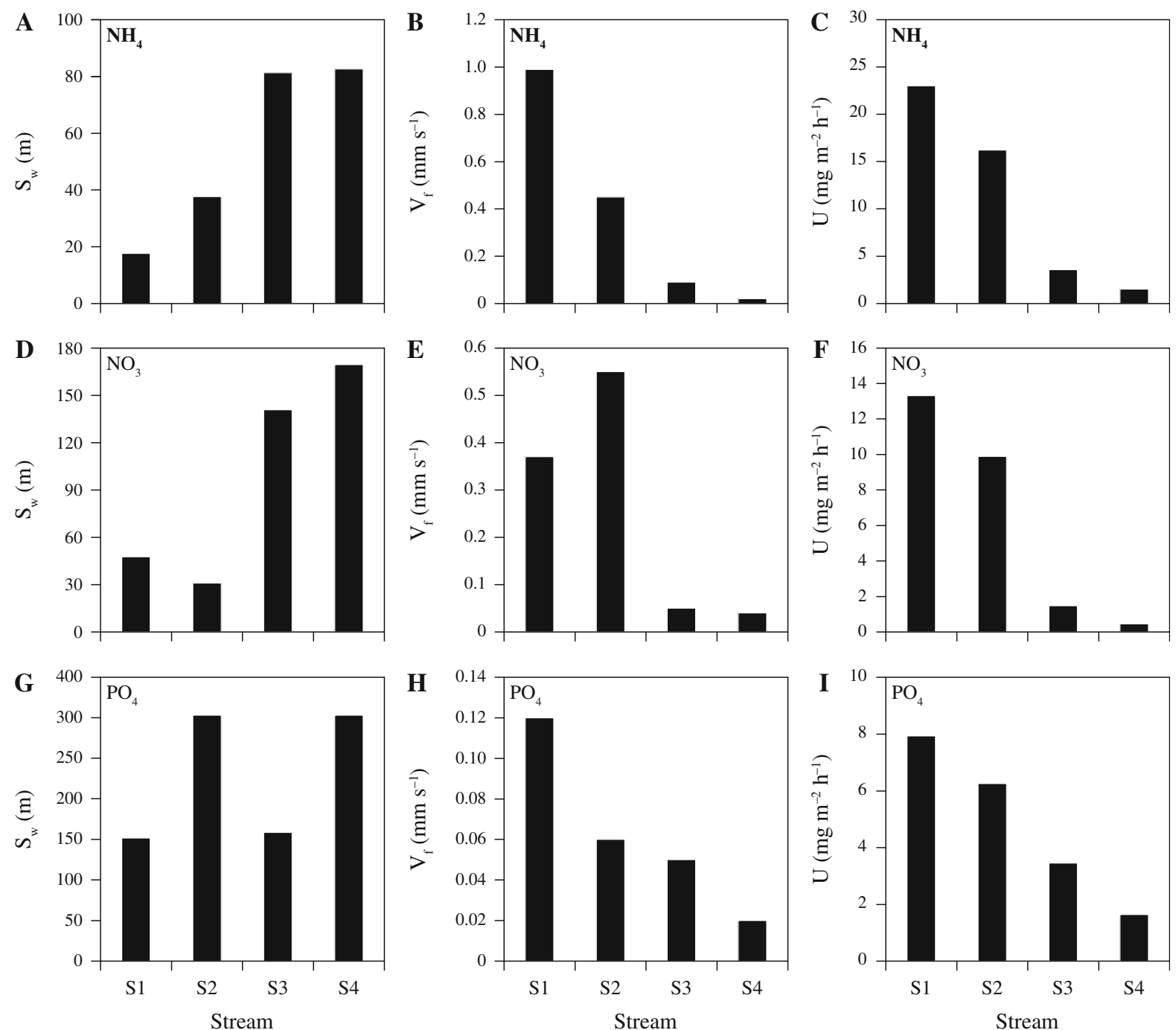

Fig. 2 Uptake metrics for $\mathrm{NH}_{4}, \mathrm{NO}_{3}$ and $\mathrm{PO}_{4}$ in the investigated streams obtained by nutrient additions. $S_{\mathrm{w}}$ is the average transport distance for nutrient molecules $(\mathrm{m}), v_{\mathrm{f}}$ is uptake velocity $\left(\mathrm{mm} \mathrm{s}^{-1}\right)$ and $\mathrm{U}$ is the area-based uptake rate $\left(\mathrm{mg} \mathrm{m}^{-2} \mathrm{~h}^{-1}\right)$

\section{Ecosystem structure}

The low macrophyte species richness observed in this study is in concordance with previous studies in the Hengill streams (Friberg et al. 2009; Woodwards et al. 2010). The observed low taxonomic richness probably reflects the geographical remoteness of Iceland and the harsh nature and low evolutionary age of these habitats (Gíslason 2005; Woodwards et al. 2010). This is clearly a restraining factor for the studies in Hengill, but the shortcomings are offset by the opportunity to study natural stream ecosystems and hereby detect more of the natural ecosystem complexity. A more detailed discussion of constraints and opportunities regarding the Hengill streams can be found in Woodwards et al. (2010).

Macrophyte species richness and total coverage increased with increasing temperature, which may be caused by temperature-induced increasing growth rates (Barko and Smart 1981) and increasing vegetative propagule germination frequencies (Spencer and Ksander 1992). The more extensive study of Friberg et al. (2009) at Hengill, however, revealed higher macrophyte coverage in some of the colder streams 
Fig. 3 Area-based nutrient uptake rates (U) for $\mathrm{NH}_{4}$, $\mathrm{NO}_{3}$ and $\mathrm{PO}_{4}$ as a function of median stream temperature (figures a, c and e, respectively) and total plant coverage (open circles) and bryophyte coverage (filled circles; figures $\mathbf{b}, \mathbf{d}$ and $\mathbf{f}$, respectively). Linear regression curves have been fitted, and $R^{2}$ values are given
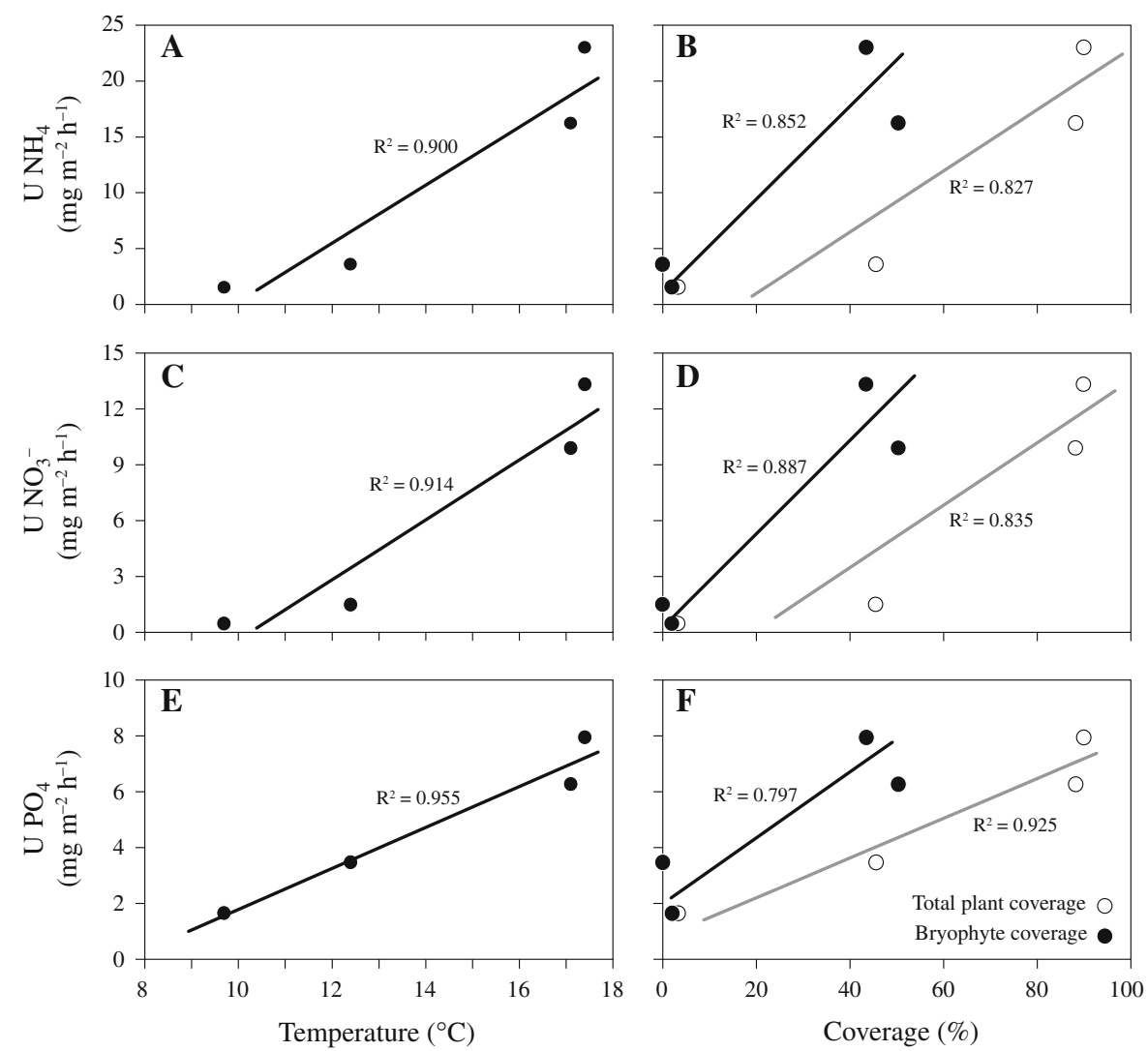

Table 2 Measured metabolic parameters (Gross primary production (GPP), community metabolism $\left(\mathrm{CR}_{24}\right)$, net daily metabolism (NDM) and $\mathrm{P} / \mathrm{R}$ relationship in four streams influenced by varying geothermal activity

\begin{tabular}{lrrrr}
\hline Parameter & \multicolumn{1}{l}{$\mathrm{S} 1$} & \multicolumn{1}{l}{$\mathrm{S} 2$} & \multicolumn{1}{l}{$\mathrm{S} 3$} & \multicolumn{1}{l}{$\mathrm{S} 4$} \\
\hline $\mathrm{GPP}\left(\mathrm{g} \mathrm{O}_{2} \mathrm{~m}^{-2} \mathrm{day}^{-1}\right)$ & 12.99 & 9.64 & 2.37 & 0.66 \\
$\mathrm{CR}_{24}\left(\mathrm{~g} \mathrm{O}_{2} \mathrm{~m}^{-2} \mathrm{day}^{-1}\right)$ & 25.46 & 14.72 & 9.44 & 5.55 \\
$\mathrm{NDM}\left(\mathrm{g} \mathrm{O}_{2} \mathrm{~m}^{-2} \mathrm{day}^{-1}\right)$ & -12.47 & -5.08 & -7.07 & -4.88 \\
$\mathrm{P} / \mathrm{R}$ & 0.61 & 0.55 & 0.25 & 0.12 \\
$k_{2}\left(\right.$ day $\left.^{-1}\right)$ & 79.5 & 98.6 & 25.6 & 84.8 \\
$k_{\text {oxygen }}\left(\right.$ day $\left.^{-1}\right)$ & 116.2 & 108.8 & 36.2 & 70.2 \\
\hline
\end{tabular}

Furthermore, estimated reaeration coefficients based on the propane injection method $\left(k_{\text {oxygen }}\right)$ and the EDM model $\left(k_{2}\right)$ are presented. Values for $k_{2}$ are adjusted for water temperature according to Elmore and West (1961). Metabolism was measured using the diurnal upstream-downstream DO change technique (Bott 2006). Calculations are based on $k_{\text {oxygen }}$ (estimated oxygen reaeration based on propane injections)

than observed in our study, indicating that temperature is not the single factor governing the distribution and abundance of macrophytes in the Hengill streams.
Other factors such as flow regimes, substratum types and self-perpetuating effects of existing vegetation (increasing propagule retention efficiency and primary colonisation success with increasing coverage (Riis 2008)) might be additional factors explaining the observed distribution and abundance of macrophyte species.

This study was conducted in four streams, and results were obtained with few replicates which clearly is a constraining factor. Interpretation of the results should therefore be conducted with care. However, based on few replicates, our study indicates distinct effects of increasing temperature in geothermally heated streams. Ecosystem primary production, respiration and nutrient uptake rates in terms of nitrate, ammonium and phosphate significantly increased with increasing temperature. The presence of macrophytes naturally increases ecosystem metabolism parameters and nutrient uptake by increasing the biomass of primary producers. However, we found that the presence of macrophytes probably further magnifies effects of increasing temperature on 

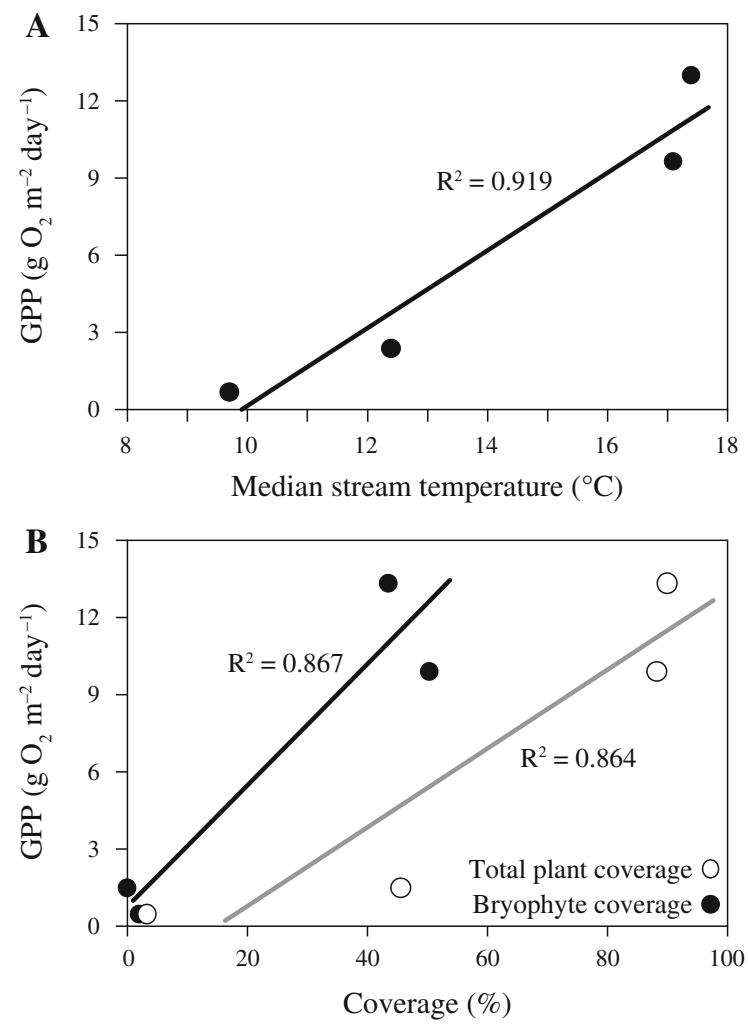

Fig. 4 Gross primary production (GPP) as a function of median stream temperature (a) and total plant (open circles) and bryophyte coverage (filled circles) (b). Linear regression curves have been fitted, and $R^{2}$ values are given

ecosystem metabolism and nutrient uptake through a combination of direct and indirect effects.

\section{Perspectives}

The model ecosystems in Hengill provide an ideal opportunity to study impacts of climate change in natural stream ecosystems. Still, the ecosystems are characterised by a relatively simple ecosystem structure, and they are geographically remote. Consequently, the extrapolation of studies at the Hengill streams to climate change scenarios in continental streams should be conducted with care. However, if our results are interpreted in a climate change context, we suggest that increasing temperature may increase rates of ecosystem processes in small light-open streams with minimal allochtonous input. Furthermore, we suggest that macrophytes might exert an increasingly important structural and functional role as temperature increases in stream ecosystems. Whether macrophytes
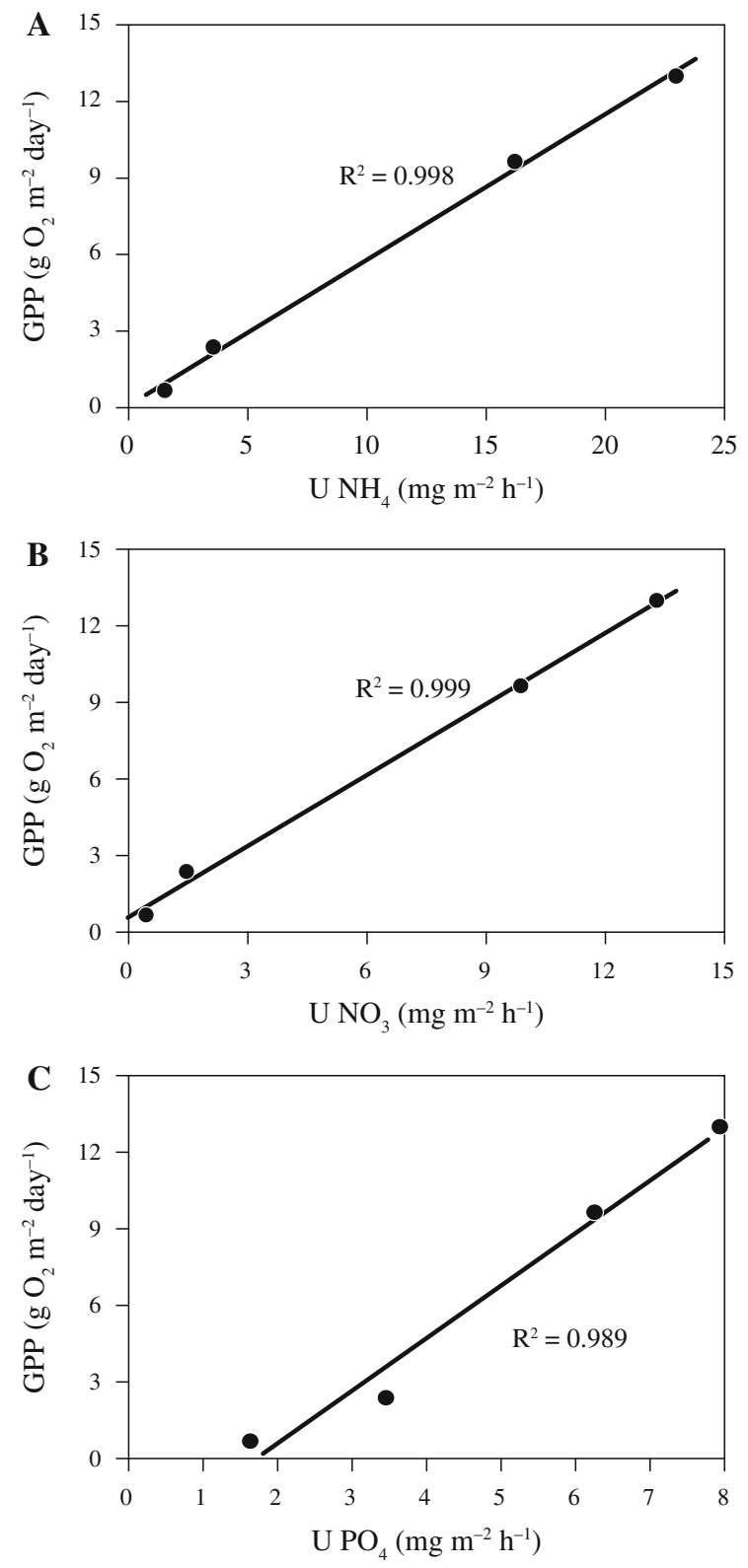

Fig. 5 Gross primary production (GPP) as a function of areabased nutrient uptake rates (U) for $\mathrm{NH}_{4}, \mathrm{NO}_{3}$ and $\mathrm{PO}_{4}(\mathbf{a}, \mathbf{b}$ and c, respectively). Linear regression curves have been fitted, and $R^{2}$ values are indicated

become more abundant in streams in the future depend on a wide array of yet unpredictable factors, including hydrological regimes, agricultural fertiliser use and length of agricultural seasons.

Acknowledgments We wish to thank G.M. Gislason, J.S. Olafsson and T.K. Jensen for field assistance and constructive 
guidance during field work, and B. Tagesen at AU for valuable assistance with chemical analyses. Furthermore, we are grateful to B. Demars and anonymous reviewers for constructive criticism on earlier drafts of the manuscript. The study was supported by the Eurolimpacs project (GOCE-CT2003-505540) and the National Environmental Research Institute, Aarhus University, Silkeborg, Denmark.

Open Access This article is distributed under the terms of the Creative Commons Attribution Noncommercial License which permits any noncommercial use, distribution, and reproduction in any medium, provided the original author(s) and source are credited.

\section{References}

Acuña V, Wolf A, Uehlinger U, Tockner K (2008) Temperature dependence of stream benthic respiration in alpine river network under global warming. Freshw Biol 53:2076-2088

Arrhenius S (1915) Quantitative laws in biological chemistry. Bell, London

Barko JW, Smart RM (1981) Comparative influences of light and temperature on the growth and metabolism of selected submersed freshwater macrophytes. Ecol Monogr 51:219-235

Bencala KE, McKnight TL, Sellweger W (1987) Evaluation of natural tracers in an acidic and metal rich stream. Water Resour Res 23:827-836

Bernot MJ, Tank JL, Royer TV, David MB (2006) Nutrient uptake in streams draining agricultural catchments of the Midwestern United States. Freshw Biol 51:499-509

Bott TL (2006) Primary productivity and community respiration. In: Hauer FR, Lamberti GA (eds) Methods in stream ecology. Academic Press, London

Brown JH, Gillolly JF, Allen JP, Savage VM, West GB (2004) Towards a metabolic theory of ecology. Ecology 85:1771-1789

Carr GM, Duthie HC, Taylor WD (1997) Models of aquatic plant productivity: a review of the factors that influence growth. Aq Bot 59:195-215

Crow GE (1993) Species diversity in aquatic angiosperms: latitudinal patterns. Aq Bot 44:229-258

Einarsson MA (1985) Climate of Iceland. In: van Loon H (ed) World survey of climatology: climates of the oceans, vol 15. Elsevier, Amsterdam

Elmore HL, West WF (1961) Effect of water temperature on stream reaeration. J Sanit Eng Div ASCE 87:59-71

Elser JJ, Dobberfuhl DR, Mackay NA, Schampel JH (1996) Organism size, life history and N:P stoichiometry: toward a unified view of cellular and ecosystem processes. Bioscience 46:674-684

Enquist BJ, Economo EP, Huxman TE, Allen AP, Ignace DD, Gillooly JF (2003) Scaling metabolism from organisms to ecosystems. Nature 423:639-642

Ensign SH, Doyle MW (2006) Nutrient spiraling in streams and river networks. J Geophys Res 111. doi:G04009/ 2005JG000114
Fellows CS, Valett HM, Dahm CN, Mulholland PJ, Thomas S (2006) Coupling nutrient uptake and energy flow in headwater streams. Ecosystems 9:788-804

Friberg N, Dybkjær JB, Olafsson JS, Gislason GM, Larsen SE, Lauridsen TL (2009) Relationships between structure and function in streams of contrasting temperature. Freshw Biol 54:2051-2068

Gessner MO, Chauvet E (2002) A case for using litter breakdown to assess functional stream integrity. Ecol Appl $12: 498-502$

Gíslason GM (2005) The origin of the freshwater fauna of the North-Atlantic Islands. Present distribution in relation to climate and possible migration routes. Verh Int Ver Theor Angew Limnol 29:198-203

Hall RO, Tank JL (2003) Ecosystem metabolism controls nitrogen uptake in streams in Grand Teton National Park, Wyoming. Limnol Oceanogr 48:1120-1128

Heino J (2002) Concordance of species richness patterns among multiple freshwater taxa: a regional perspective. Biodivers Conserv 11:137-147

Hickling RRB, Roy J, Hill K, Fox R, Thomas CD (2006) The distributions of a wide range of taxonomic groups are expanding polewards. Global Change Biol 12:450-455

IPCC (2007) Technical summary. In: Pachauri RK (ed) Climate change 2007: the phisical science basis. Contribution of working group 1 to the fourth assessment report of the intergovernmental panel on climate change. Cambridge University Press, Cambridge

Jacobsen D, Schulz R, Encalada A (1997) Structure and diversity of stream invertebrate assemblages: the influence of temperature with altitude and latitude. Freshw Biol 38:247-261

Kelly MG, Thyssen N, Moeslund B (1983) Light and the annual variation of oxygen- and carbon-based measurements of productivity in a macrophyte-dominated river. Limnol Oceanogr 28:503-515

Kjeldahl J (1883) A new method for the determination of nitrogen in organic matter. Fresenius Zeitschrift für Analytische Chemie 22:366

Lacoul P, Freedman B (2006) Environmental influences on aquatic plants in freshwater ecosystems. Environ Rev 14:89-136

Maberly SC (1985) Photosynthesis by Fontinalis antipyretica. I. Interaction between photon irradiance, concentration of carbon dioxide and temperature. New Phytol 100:127-140

Marzolf ER, Mulholland PJ, Steinman AD (1994) Reply: improvements to the diurnal upstream-downstream technique for determining whole-stream metabolism in small streams. Can J Fish Aquat Sci 51:1591-1599

McKnight DM, Runkel RL, Tate CM, Duff JH, Moorhead DL (2004) Inorganic N and P dynamics of Antarctic glacial meltwater streams as controlled by hyporheic exchange and benthic autotrophic communities. J N Am Benthol Soc 23:171-188

Mulholland PJ, Newbold JD, Elwood JW, Ferren LA, Webster JR (1985) Phosphorous spiraling in woodland streams: seasonal variations. Ecology 66:1012-1023

Mulholland PJ, Fellows CS, Tank JL, Grimm NB, Webster JR, Hamilton SK, Martí E, Ashkenas L, Bowden WB, Dodds WK, McDowell WH, Paul MJ, Peterson MJ (2001) Inter- 
biome comparison of factors controlling stream metabolism. Freshw Biol 46:1503-1517

Mulholland PJ, Tank JL, Webster JR, Bowden WB, Dodds WK, Gregory SV, Grimm NB, Hamilton SK, Johnson SL, Marti E, McDowell WH, Merriam J, Meyer JL, Peterson BJ, Valett HM, Wollheim WM (2002) Can uptake length in streams be determined by nutrient addition experiments? Results from an inter-biome comparison study. J N Am Benthol Soc 21:544-560

Mulholland PJ, Thomas SA, Valett HM, Webster JR, Beaulieu $\mathrm{J}$ (2006) Effects of light on $\mathrm{NO}_{3}{ }^{-}$uptake in small forested streams: diurnal and day-to-day variations. J N Am Benthol Soc 25:583-595

Payn RA, Webster JR, Mulholland PJ, Valett HM, Dodds WK (2005) Estimation of stream nutrient uptake from nutrient addition experiments. Limnol Oceanogr Methods 3:174-182

Petersen I, Masters Z, Hildrew AG, Ormerod J (2004) Dispersal of adult aquatic insects in catchments of different land use. J Appl Ecol 41:934-950

Pilon J, Santamaría L (2001) Seasonal acclimation in the photosynthetic and respiratory temperature responses of three submerged freshwater macrophyte species. The New Phytol 151:659-670

Rathbun RF, Stephens RW, Schultz DJ, Tai DY (1978) Laboratory studies of gas transfer for reaeration. J Environ Eng 104:2377-2385

Redfield AC (1958) The biological control of chemical factors in the environment. Am Sci 46:205-221

Riis T (2008) Dispersal and colonization of plants in lowland streams: success rates and bottlenecks. Hydrobiologia 596:341-351

Rosenfeld JS, Mackay RJ (1987) Assessing the food base of stream ecosystems: alternatives to the $\mathrm{P} / \mathrm{R}$ ratio. Oikos 50:141-147
Rowe JM, Meegan SK, Engstrom ES, Perry SA, Perry WB (1996) Comparison of leaf processing rates under different temperature regimes in three headwater streams. Freshw Biol 36:2277-2288

Simon KS, Townsend CR (2005) Temporal variation of N and $\mathrm{P}$ uptake in 2 New Zealand streams. J N Am Ben Soc 24:1-18

Spencer DF, Ksander GG (1992) Influence of temperature and moisture on vegetative propagule germination of Potamogeton species: implications for aquatic plant management. Aq Bot 67:237-249

Stream Bryophyte Group (1999) Roles of bryophytes in stream ecosystems. J N Am Benthol Soc 18:151-184

Stream Solute Workshop (1990) Concepts and methods for assessing solute dynamics in stream ecosystems. J N Am Benthol Soc 9:95-119

Tsivoglu HC, Neal LA (1976) Tracer measurement of reaeration: III. Predicting the reaeration capacity of inland streams. J Wat Pol Con Fed 489:2669-2689

Vallett HM, Thomas SA, Mulholland PJ, Webster JR, Dahm CN, Fellows CS, Crenshaw CL, Peterson CG (2008) Endogenous and exogenous control of ecosystem function: $\mathrm{N}$ cycling in headwater streams. Ecology 89:3515-3527

Ward JV, Stanford JA (1982) Thermal responses in the evolutionary ecology of aquatic insects. Ann Rev Entomol 27:97-117

Webster JB, Valett HM (2006) Solute dynamics. In: Hauer FR, Lamberti GR (eds) Methods in stream ecology. Academic Press, London

Woodwards G, Dybkjær JB, Ólafsson JS, Gíslason GM, Hannesdóttir ER, Friberg N (2010) Sentinel systems on the razor's edge: effects of warming on Arctic stream ecosystems. Global Change Biol 16:1979-1991 